\title{
Juvenile dermatomyositis: clinical and laboratory charateristics of 18 patients
}

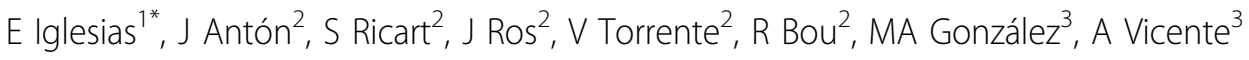 \\ From 18th Pediatric Rheumatology European Society (PReS) Congress \\ Bruges, Belgium. 14-18 September 2011
}

\section{Introduction}

Juvenile Dermatomyositis (JDM) is the most common idiopathic inflammatory myopathy in childhood, a systemic vasculopathy that affects usually skin, skeletal muscle, gastrointestinal tract and other organs. The diagnosis is made by criteria and the goals of treatment include control the underlying myositis and prevent disease and treatment complications. Stepwise aggressive treatment decrease long term sequelae and improve outcomes with a more rapid normalization of muscle inflammation.

\section{Methods}

We studied demographics, epidemiology, clinical and laboratory characteristics in a descriptive observational study of 18 children with JDM assisted at our hospital from January 2000 to November 2010.

\section{Results}

$72.2 \%$ of patients were females. Mean age at disease onset was 7.36 years. Most common presenting features were cutaneous and weakness. Medium time between first signs/symptoms and diagnosis was 59 days. 81.2\% had pathological CK at diagnosis. CMAS was pathological in $85.7 \%$ of patients, electromyography in $84.61 \%$ and magnetic resonance image (MRI) in all patients that was made. Muscular biopsy was compatible with JDM in $83.33 \%$. Medium time between first symptoms and treatment beginning was 1.94 months. Drugs more frequently used were corticosteorids, methotrexate, hidroxicloroquine and intravenosus immunoglobulines. Time to response was 7.12 months. $50 \%$ of patients had disease relapse $(66.6 \%$ of them with normal muscular enzymes) and medium time for it was 6.63 months.

\footnotetext{
* Correspondence: estibaliziglesias@hotmail.com

'Department of Pediatric Infectious Diseases and Immunodeficiencies,

Hospital Infantil Virgen del Rocío, Seville, Spain

Full list of author information is available at the end of the article
}

Actually, 7/16 patients have reached clinical remission, 6/16 complete clinical response, 2/16 clinical response.

\section{Conclusions}

1. Other myositis-enzymes than CK should be tested at diagnosis.

2. MRI could evaluate muscular edema with a no invasive technique.

3. Muscular enzymes are a good tool to monitor disease activity but in some patients won't be useful, so we have to consider MRI and other activity markers.

\section{Author details}

${ }^{1}$ Department of Pediatric Infectious Diseases and Immunodeficiencies, Hospital Infantil Virgen del Rocío, Seville, Spain. ${ }^{2}$ Pediatric Rheumatology Unit. ${ }^{3}$ Department of Dermatology, Hospital Sant Joan de Deu, Esplugues de Llobregat, Barcelona, Spain.

Published: 14 September 2011

\section{doi:10.1186/1546-0096-9-S1-P50}

Cite this article as: Iglesias et al: Juvenile dermatomyositis: clinical and laboratory charateristics of 18 patients. Pediatric Rheumatology 20119 (Suppl 1):P50.

Submit your next manuscript to BioMed Central and take full advantage of:

- Convenient online submission

- Thorough peer review

- No space constraints or color figure charges

- Immediate publication on acceptance

- Inclusion in PubMed, CAS, Scopus and Google Scholar

- Research which is freely available for redistribution 